\title{
Penerapan Pembelajaran Berbasis STEM untuk Meningkatkan Hasil Belajar IPA
}

\author{
Ni Putu Wahyuni ${ }^{1^{*}}$
}

${ }^{1}$ SMP Negeri 2 Gianyar, Bali, Indonesia

\section{A R T I C L E I N F O}

Article history:

Received 19 October 2020

Received in revised form

10 November 2020

Accepted 10 January 2021

Available online 01

February 2021

\section{Kata Kunci:}

Pembelajaran Berbasis

STEM, Hasil Belajar

Keywords:

STEM Based Learning,

Learning Outcomes

\begin{abstract}
A B S T R A K
Hasil belajar IPA yang rendah disebabkan karena guru kurang bervariasi menggunakan model pembelajaran sehingga siswa merasa kesulitan dalam memahami materi pembelajaran. Penelitian ini bertujuan untuk menganalisis penerapan pembelajaran berbasis STEM dalam meningkatkan hasil belajar IPA siswa SMPN. Penelitian ini merupakan Penelitain Tindakan Kelas (PTK) yang dilaksanakan dalam 2 siklus, setiap siklus dilakukan penerapan dengan pembelajaran berbasis STEM. Subjek penelitian ini berjumlah 34 siswa. Teknik pengumpulan data melalui tes dan wawancara. Teknik analisis data yang digunakan adalah analisis deskriptif. Hasil penelitian ini menunjukan pada awal pengamatan nilai rata-ratanya hanya 44,26 , pada siklus I menjadi 75,44 dan siklus II naik menjadi secara signifikan menjadi 92,65. Daya serap dan Ketuntasan Hasil belajar pada pengamatan awal (observasi) sebelum dilakukan tindakan adalah $44,26 \%$ dan $14,71 \%$, siklus I menunjukkan daya serap dan ketuntasan kelas menjadi adalah $75,44 \%$ dan $76,47 \%$ yang berada pada kategori sangat tinggi sedang pada siklus II daya serap dan ketuntasan kelas meningkat pesat menjadi $92,65 \%$ dan $100 \%$. Dapat disimpulkan bahwa pembelajaran berbasis STEM dapat meningkatkan hasil belajar IPA. Implikasi penelitian ini memberikan dampak menciptakan suasana pembelajaran menjadi lebih aktif sehingga dapat meningkatkan hasil belajar siswa.
\end{abstract}

A B S T R A K

The low science learning outcomes are due to the lack of variation in teachers using the learning model so that students find it difficult to understand the learning material. This study aims to analyze the application of STEM-based learning in improving science learning outcomes of Junior High Scholl students. Research. STEM-Based Learning, this learning outcome is a classroom action research that is carried out in 2 cycles, each cycle is implemented with STEM-based learning. The subjects of this study were 34 students. Data collection techniques through tests and interviews. The data analysis technique used is descriptive analysis. The results of this study indicate that at the beginning of the observation, the average value was only 44.26, in the first cycle it became 75.44 and the second cycle increased significantly to 92.65. Absorption and Completeness Learning outcomes in the initial observation (observation) before taking action were $44.26 \%$ and $14.71 \%$, the first cycle showed the absorption and completeness of the class to be $75.44 \%$ and $76.47 \%$ which were in the very category. medium-high in the second cycle the absorption and completeness of the class increased rapidly to $92.65 \%$ and $100 \%$. It can be concluded that STEM-based learning can improve science learning outcomes. The implication of this research has the impact of creating a more active learning atmosphere so that it can improve student learning outcomes.

\section{Pendahuluan}

Ilmu Pengetahuan Alam (IPA) adalah materi pelajaran yang terdapat pada kurikulum 2013. Redhana (2013) menyatakan bahwa IPA merupakan kegiatan yang dilakukan untuk memahami alam 
semesta melalui pengatan dan menggunakan prosedur tertentu untuk mendapatka sebuah kesimpulan. Dengan mempelajari IPA seseorang dapat mengenal mengenai makhluk hidup dan alam sekitar (Pratama, dkk, 2017; Rahayu, 2017). Siswa yang mempelajari IPA akan dapat menerapkan ilmunya dalam kehidupan sehari-hari sehingga pembelajaran ini dianggap sangat penting dan harus dipahami oleh siswa. Berbagai upaya telah dilakukan pemerintah untuk memajukan pendidikan IPA di sekolah. Untuk memaksimalkan pembelajaran di kelas maka diperlukan sebuah strategi, sarana penunjang, serta model pembelajaran inovatif yang memudahkan proses pembelajaran di kelas. salah satu cara dalam meningkatkan hasil belajar IPA adalah dengan menggunakan model pembelajaran yang kreatif dan inovatif (Febriana, 2017; Kurnia, Damayani, \& Kiswoyo, 2019; Yuliati \& Lestari, 2019).

Permasalahan yang sering terjadi saat ini adalah guru belum menggunakan model pembelajaran inovatif yang dapat meningkatkan motivasi siswa dalam belajar (Ari, N. L. P. M., \& Wibawa, 2019; Wulandari, Sudatha, \& Simamora, 2020). Guru lebih dominan menggunakan model pembelajaran konvensional sehingga siswa merasa bosan jika belajar di kelas. hal ini akan berpengaruh pada pencapaian kompetensi pengetahuan IPA yang kurang optimal. Permasalahan ini juga ditemuan pada salah satu sekolah menengah pertama. Berdasarkan hasil observasi di SMP Negeri 2 Gianyar ditemukan bahwa kualitas hasil belajar IPA dari peserta didik masih rendah. Nilai siswa kelas VIII untuk mata pelajaran IPA sebagian besar masih berada di bawah kriteria ketuntasan minimal (KKM) yaitu 62. Sebagai bukti hasil pada materi klasifikasi benda di kelas VIII D nilai rata-rata yang diperoleh peserta didik adalah 44,26, dan lebih dari $85 \%$ di antara peserta didik belum mencapai ketuntasan. Rendahnya perolehan hasil belajar tersebut disebabkan oleh kurang termotivasinya siswa untuk belajar. Hal itu dapat dilihat dari rendahnya partisipasi aktif peserta didik dalam proses pembelajaran. Selama ini, proses pembelajaran IPA masih menggunakan paradigma lama dimana guru memberikan pengetahuan kepada peserta didik yang pasif. Guru mengajar dengan metode konvensional, yaitu metode ceramah dan mengharapkan peserta didik duduk, diam, dengar, catat dan hapal (3DCH) sehingga Kegiatan Belajar Mengajar (KBM) menjadi monoton dan kurang menarik perhatian peserta didik. Kondisi seperti itu tidak akan meningkatkan kemampuan peserta didik dalam memahami mata pelpelajaran IPA. Akibatnya hasil belajar yang dicapai peserta didik tidak sesuai yang diharapkan. Model penilaian seperti ini menyebabkan peserta didik cenderung belajar hanya pada saat menjelang ulangan saja dan tidak termotivasi mempelajari IPA secara tuntas, mendalam, dan berkelanjutan.

Proses pembelajaran seharusnya dapat menarik perhatian dan minat siswa sehingga tujuan pembelajaran dapat tercapai secara maksimal (Anika \& Fajar, 2020; Hartanti, Fidiyanti, Ruhimat, \& Winarti, 2017). Pembelajaran yang kurang menarik akan membuat siswa merasa bosan dalam belajar sehingga berpengaruh pada hasil belajar siswa yang rendah. Merancang pembelajaran yang inovatif menjadi tantangan sulit untuk diwujudkan oleh guru, sehingga rancangan pembelajaran yang tidak sesuai berdampak pada ketercapaian hasil belajar siswa (Putri, Kusmariyatni, \& Murda, 2018; Putri, Suwatra, \& Tegeh, 2018). Memperhatikan permasalahan di atas, sudah selayaknya dalam pembelajaran IPA dilakukan suatu inovasi. Jika yang terjadi sebagain besar kegiatan pembelajaran dilakukan oleh peserta didik, maka dalam penelitian ini akan diupayakan peningkatan pemahaman peserta didik melalui pengembangan keterampilan abad 21 yang berperan penting dalam menciptakan peradaban sebuah negara yang ditandai dengan kemajuan di bidang teknologi dan informasi. Jones \& Zanker (2013) menyampaikan 4 ketrampilan (4C) yang dibutuhkan pada keterampilan abad 21, antara lain: (1) Critical Thinking and Problem Solving, mempunyai pemikiran yang kritis dalam menyelesaikan masalah; (2) Creativity and Innovation, mempunyai kreatifitas dan inovasi; (3) Communication, mempunyai kemampuan dalam mendengar, membaca, berbicara dan menulis dengan menggunakan berbagai media; (4) Collaboration, mempunyai kemampuan dalam bekerjasama dan menghargai orang lain. Pendekatan pembelajaran yang dapat diterapkan pada abad 21 ini adalah STEM (Science, Technology, Engineering, and Mathematics).

STEM merupakan salah satu terbosan penting yang sesuai dengan pengembangan keterampilan abad 21 marajuk pada suatu pendekatan interdisipliner yang mempelajari konsep akademik yang dihubungkan dengan dunia nyata dan menerapkan prinsip-prinsip sains, matematika, rekayasa dan teknologi (Kanematsu \& Barry, 2016; Salame \& Nazir, 2019). Pada awal perkembangannya STEM telah diterapkan di sejumlah negara maju seperti Amerika Serikat, Jepang, Finlandia, Australia dan Singapura. STEM merupakan inisiatif dari National Science Foundation. Tujuan dari penerapan STEM di Amerika Serikat ialah untuk menjadikan keempat bidang ini (science, technology, engineering, and mathematics) menjadi pilihan karir utama bagi peserta didik (Kapila \& Iskander, 2014). Keadaan ini terjadi karena negara tersebut mengalami krisis ilmuan di bidang STEM. Bentuk keseriusan pemerintah Amerika Serikat untuk mengatasi masalah tersebut antara lain dengan mendirikan STEM Education dan memberikan bantuan biaya pendidikan pada calon mahasiswa yang memilih salah satu bidang STEM (Jones \& Zanker, 2013). Namun beberapa tahun belakangan, STEM diterapkan pada berbagai bidang studi atau jurusan di berbagai jenjang pendidikan. Kriteria dimana dengan menggunakan pembelajaran berbasis STEM, peserta 
didik harus dapat berperan sebagai (1) pemecah masalah, (2) innovator, (3) penemu, (4) pemikir logikal, dapat memperbaiki dan mengembangkan keterampilan yang baru diberikan, (5) self-relansi, dan (6) melek teknologi (Nuraziza \& Suwarma, 2018; Octaviyani, Kusumah, \& Hasanah, 2020). Secara umum pembelajaran berbasis STEM memiliki tujuan dan manfaat antara lain: (1) Mengasah keterampilan berpikir kritis dan kreatif, logis, inovatif dan produktif; (2) Menanamkan semangat gotong royong dalam memecahkan masalah; (3) Mengenalkan perspektif dunia kerja dan mempersiapkannya; (4) Memanfaatkan teknologi untuk menciptakan dan mengomunikasikan solusi yang inovatif; (5) Media untuk menumbuhkembangkan kemampuan menemukan dan menyelesaikan masalah; (6) Media untuk merealisasikan kecakapan abad 21 dengan menghubungkan pengalaman kedalam proses pembelajaran melalui peningkatan kapasitas dan kecakapan peserta didik; (7) Standar Literasi Teknologi (Octaviyani et al., 2020; Torlakson, 2014).

Penerapan pembelajaran berbasis STEM akan lebih memotivasi peserta didik untuk berprestasi dan memperoleh nilai terbaik serta dapat memotivasi peserta didik untuk lebih aktif dalam diskusi. Penelitian yang dilakukan oleh Twiningsih \& Sayekti (2020) menyatakan bahwa penerapan pembelajaran berbasis STEM dapat meningkatkan keterampilan siswa sehingga berpengaruh pada peningkatan hasil belajar siswa. Penelitian yang dilakukan oleh Octaviyani et al. (2020) menyatakan bahwa penerapan pembelajaran berbasis STEM dapat meningkatkan kemampuan berpikir kreatif siswa sehingga berpengaruh pada peningkatan prestasi siswa.

Berdasarkan uraian maka dapat disimpulkan bahwa penerapan Pembelajaran Berbasis STEM dapat meningkatkan hasil belajar IPA peserta. Dipilihnya pembelajaran berbasis STEM karena untuk memecahkan masalah secara sistematis, diperlukan krativitas dalam menerapkan prinsip-prinsip ilmiah. Hal tersebut hanya dapat dipecahkan jika kita dapat mengubah pola pikir kita sesuai dengan perkembangan keterampilan abad 21 dengan membuat suasana belajar menjadi menyenangkan, sehingga peserta didik maupun pendidik menikmati proses pembelajaran. Tujuan penelitian ini adalah untuk menganalisis penerapan pembelajaran berbasis STEM dalam meningkatkan hasil belajar IPA peserta didik di SMPN 2 Gianyar Tahun Pelajaran 2018/2019. Melalui integrasi STEM ini, diharapkan dapat (1) memperdalam, memperluas, dan meningkatkan pemahaman peserta didik.

\section{Metode}

Penelitian ini dilakukan di kelas VIII D SMP Negeri 2 Gianyar tahun pelajaran 2018/2019 semester ganjil dengan alasan karena di kelas ini pada saat proses pembelajaran teridentifikasi berbagai masalah yang menyebabkan kegiatan belajar mengajar di kelas tersebut: memiliki hasil belajarnya masih rendah, memiliki minat yang rendah dalam pembelajaran IPA, dan masih belum optimal dalam menyerap pembelajaran IPA, sehingga berdampak pada rendahnya nilai hasil belajar IPA peserta didik. Materi yang dipilih adalah pesawat sederhana dengan Kompetensi dasar yang dipilih adalah KD 3.3 menjelaskan konsep usaha, pesawat sederhana, dan penerapannya dalam kehidupan sehari-hari termasuk kerja otot pada struktur rangka manusia, dan 4.3 Menyajikan hasil penyelidikan atau pemecahan masalah tentang manfaat penggunaan pesawat sederhana dalam kehidupan sehari-hari" dengan indikatornya adalah (1) Mengamati cara kerja pesawat sederhana secara langsung/video; (2) Mengidentifikasi jenis pesawat sederhana seperti katrol, roda berporos, bidang miring; (3) Melakukan percobaan dan mengidentifikasi mekanisme kerja pesawat sederhana serta hubungannya dengan kerja otot pada struktur rangka manusia; (4) Melaporkan/memaparkan hasil penyelidikan tentang manfaat pesawat sederhana dalam kehidupan sehari-hari. Penelitian ini dirancang dan dilaksanakan dalam dua siklus pembelajaran. Setiap siklus terdiri atas empat tahap yaitu perencanaan tindakan, pelaksanaan tindakan, pengamatan dan refleksi. Secara garis besar penelitian ini dapat seperti Gambar 1 .

Subjek penelitian adalah seluruh peserta didik kelas VIII D yang berjumlah 34 peserta didik dan terdiri atas 15 laki-laki dan 19 perempuan di lingkungan SMP Negeri 2 Gianyar semester ganjil tahun pelajaran 2018/2019 pada materi pesawat sederhana. Data yang dikumpulkan dalam penelitian ini adalah data tes hasil belajar yang dilaksanakan pada akhir setiap siklus dengan menggunakan pembelajaran berbasis STEM. Data diambil secara langsung oleh peneliti dan untuk data hasil belajar peserta didik adalah berupa data kuantitatif karena data hasil belajar peserta didik diambil dalam bentuk angka. Untuk memperoleh data tersebut di atas digunakan teknik tes yang dilakukan untuk memperoleh data hasil belajar peserta didik berupa tes dengan bentuk objektif yang dilakukan pada tiap-tiap akhir siklus yang merupakan tugas individu pada tiap akhir siklus. Instrumen pengumpulan data dapat ditunjukkan pada Tabel 1. 


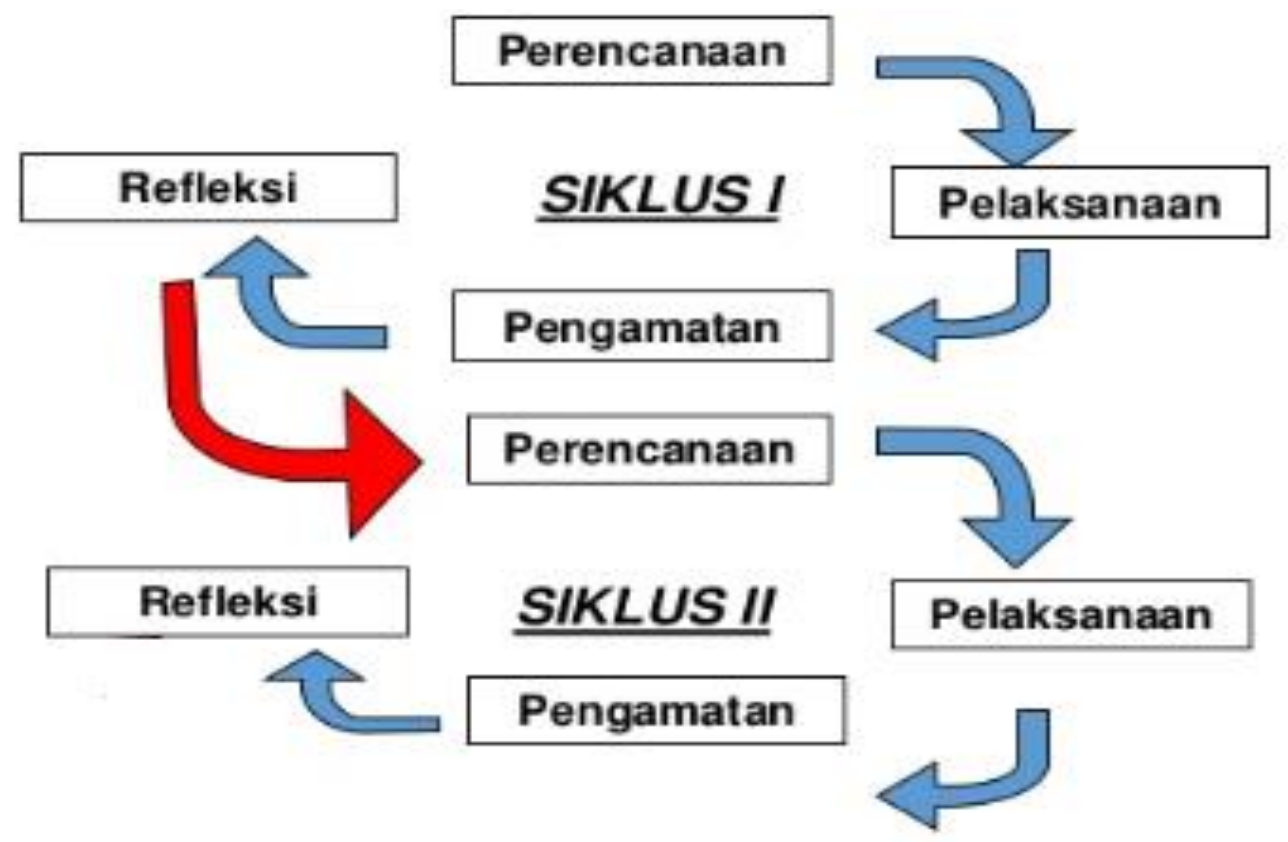

Gambar 1. Desain Penelitian Tindakan Kelas

Teknik pengumpulan data yang digunakan untuk menilai tingkat keberhasilan peserta didik adalah intrumen tes. Intrumen tes adalah alat untuk memperoleh data hasil belajar yang telah diberikan kepada peserta didik. Sedangkan untuk tes yang digunakan adalah tes tertulis berupa soal pilihan ganda sebanyak 20 butir soal dimana setiap item yang benar memperoleh nilai 1 dan salah diberi nilai 0 . Data yang dikumpulkan dalam penelitian ini adalah data hasil belajar pada materi Pesawat Sederhana dengan menggunakan pembelajaran berbasis STEM. Instrumen dan metode pengumpulan data yang digunakan dalam penelitian ini disajikan Tabel 1.

Tabel 1. Instrumen Pengumpulan Data

\begin{tabular}{lccc}
\hline \multicolumn{1}{c}{ Materi } & Metode & Pengumpulan Data & Waktu Pelaksanaan \\
\hline Tuas dan bidang miring & Tes & Tes Hasil belajar & Akhir pembelajaran siklus 1 \\
Katrol dan roda berporos & Tes & Tes Hasil belajar & Akhir pembelajaran siklus 2 \\
\hline
\end{tabular}

Teknik analisis data yang digunakan dalam pengolahan data ini adalah metode analisis deskriptif yaitu cara pengolahan data dengan mengguakan rumus-rumus yang sederhana guna memperoleh kesimpulan umum. Kesimpulan umum yang dimaksud adalah kesimpulan yang bersifat menyeluruh mengenai permasalahan yang dibahas

\section{Hasil dan Pembahasan}

Data yang diperoleh terkait dengan pelaksanaan rencana tindakan kelas yang mencakup data hasil belajar peserta didik. Data-data ini selanjutnya digunakan untuk menjawab masalah-masalah yang dirumuskan dalam penelitian yang berjudul Penerapan pembelajaran berbasis STEM untuk meningkatkan hasil belajar IPA peserta didik pada materi Pesawat Sederhana di kelas VIII D SMP Negeri 2 Gianyar tahun pelajaran 2018/2019. Rincian pelaksanaan masing-masing siklus adalah sebagai berikut: 1) Tindakan pada sisklus 1 dilaksanakan sesuai rencana yang dirancang bersama guru sejawat. Siklus I dilaksanakan sebanyak 3 kali pertemuan ( 2 pertemuan untuk proses dan 1 pertemuan untuk tes hasil belajar siklus I). Dengan materi yang dibahas meliputi KD 3.3 yaitu Menjelaskan konsep usaha, pesawat sederhana, dan penerapannya dalam kehidupan sehari-hari termasuk kerja otot pada struktur rangka manusia dan KD 4.3 yaitu Menyajikan hasil penyelidikan atau pemecahan masalah tentang manfaat penggunaan pesawat sederhana dalam kehidupan sehari-hari. 2) Tindakan pada siklus II dilaksanakan sebanyak 3 kali pertemuan ( 2 pertemuan untuk proses dan 1 pertemuan untuk tes hasil belajar siklus II). Berdasarkan data yang dihasilkan dapat dinyatakan bahwa hasil belajar pengamatan/observasi, pada siklus I, dan pada siklus II menunjukkan nilai rata-rata kelas yang kian meningkat. Hal ini dapat dilihat pada Tabel 2. 
Tabel 2. Interval Data Ketuntasan Hasil Belajar Peserta Didik Siklus I dan II

\begin{tabular}{ccccc}
\hline No & Interval & Observasi & Siklus I & Siklu II \\
\hline 1 & $<62$ & 26 & 8 & 0 \\
2 & $62-75$ & 3 & 5 & 3 \\
3 & $76-87$ & 4 & 11 & 5 \\
4 & $88-100$ & 1 & 10 & 26 \\
\hline
\end{tabular}

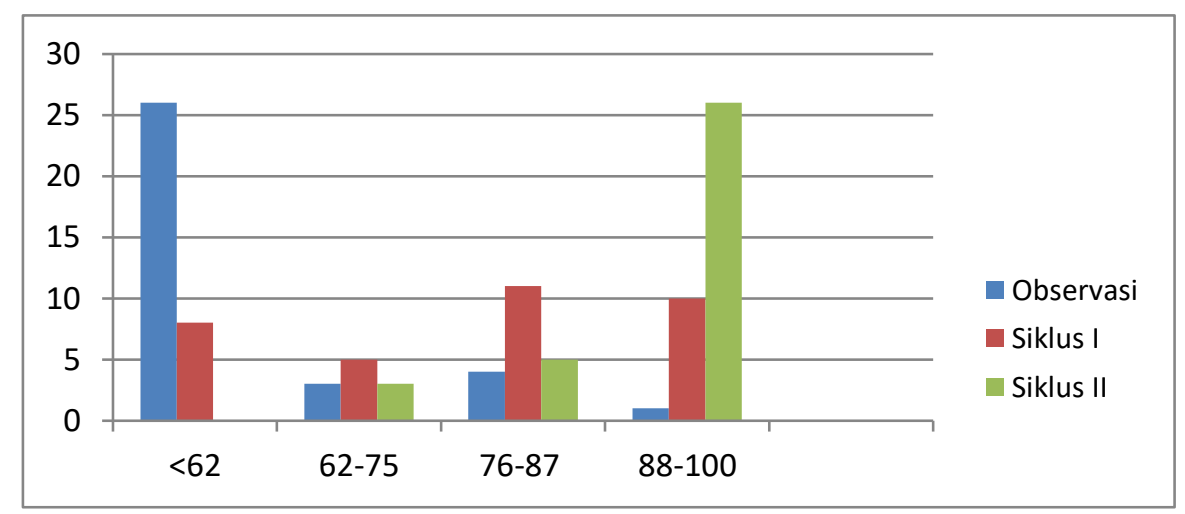

Gambar 2. Grafik Data Ketuntasan KKM Hasil Belajar Peserta Didik

Hasil belajar pada pengamatan awal (observasi) sebelum dilakukan tindakan adalah 44,26, siklus I menunjukkan rata-rata kelas menjadi adalah 75,44 yang berada pada kategori sangat tinggi sedang pada siklus II rata-rata kelas meningkat pesat menjadi 92,65.

Tabel 3. Perbandingan Hasil Rata-Rata Kelas

\begin{tabular}{|c|c|c|}
\hline No & Rata-Rata Kelas & Nilai \\
\hline 1 & Data Observasi & 44,26 \\
\hline 2 & Siklus I & 75,44 \\
\hline 3 & Siklus II & 92,65 \\
\hline
\end{tabular}

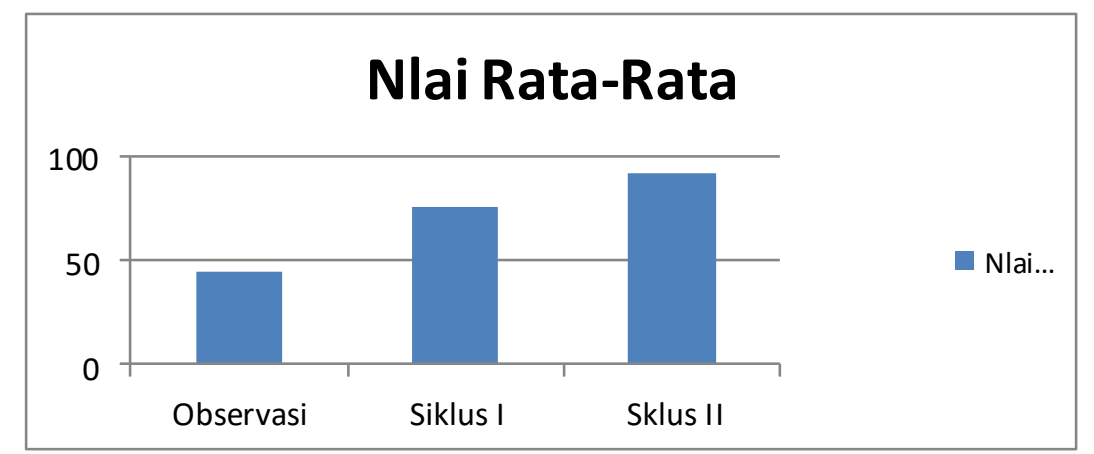

Gambar 3. Grafik Data Perbandingan Hasil Rata-Rata Kelas

Daya serap dan Ketuntasan Hasil belajar pada pengamatan awal (observasi) sebelum dilakukan tindakan adalah 44,26\% dan 14,71\%, siklus I menunjukkan daya serap dan ketuntasan kelas menjadi adalah $75,44 \%$ dan $76,47 \%$ yang berada pada kategori sangat tinggi sedang pada siklus II daya serap dan ketuntasan kelas meningkat pesat menjadi 92,65\% dan 100\%. 
Tabel 4. Perbandingan Hasil Daya Serap dan Ketuntasan Kelas

\begin{tabular}{clcc}
\hline No & \multicolumn{1}{c}{ Daya Serap \& Ketuntasan } & Daya Serap & Ketuntasan \\
\hline 1 & Data Observasi & $44,26 \%$ & $14,71 \%$ \\
2 & Siklus I & $75,44 \%$ & $76,47 \%$ \\
3 & Siklus II & $92,65 \%$ & $100 \%$ \\
\hline
\end{tabular}

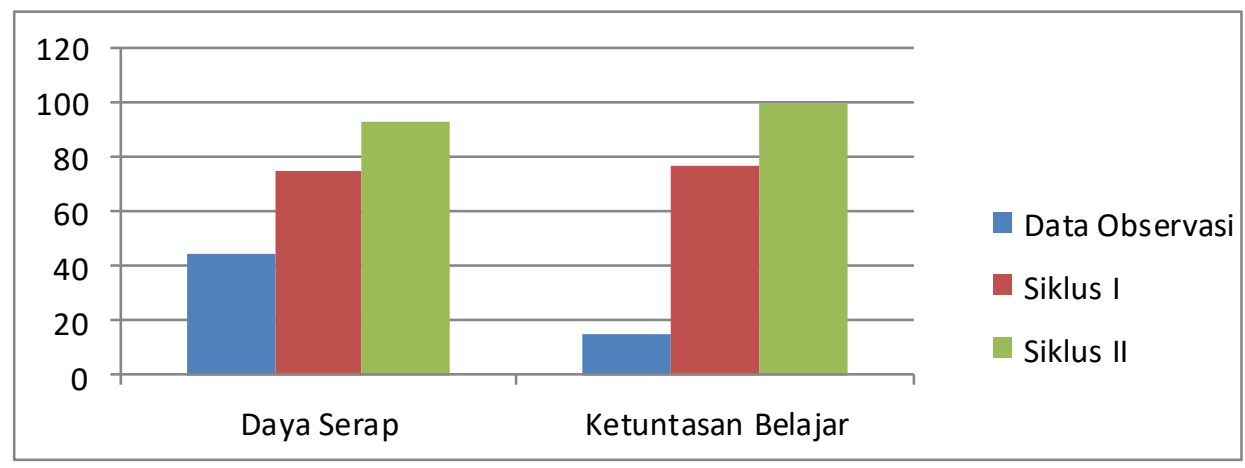

Gambar 4. Grafik Data Perbandingan Daya Serap dan Ketuntasan Hasil Belajar IPA

Data saat pengamatan atau sebelum tindakan menunjukkan rata-rata hasil belajar yang berada pada kategori rendah yaitu 44,26 dengan daya serap dan ketuntasan masing-masing adalah $44,26 \%$ dan $14,71 \%$. Pada siklus I rata-rata yang diperoleh sebesar 75,44 dengan kategori sangat tinggi. Daya serap $75,44 \%$ berada pada kategori sangat tinggi di skala 4 yang ditunjukkan pada tabel 2.3 dengan ketuntasan belajar peserta didik mencapai $76,47 \%$. Hasil dari tes hasil belajar peserta didik yang merupakan tes objektif memforsir peserta didik untuk betul-betul dapat memahami apa yang sudah dipelajari. Nilai ratarata peserta didik pada siklus I yang sebesar 75,44 menunjukkan bahwa peserta didik setelah menguasai sebagian besar materi yang diajarkan walaupun belum begitu sempurna. Hasil ini menunjukkan peningkatan kemampuan peserta didik menguasai mata pelajara IPA jika dibandingkan saat pengamatan.

Hasil tes hasil belajar peserta didik di siklus I telah menunjukkan adanya efek penggunaan pembelajaran berbasis STEM yang ditunjukkan dengan peningkatan perolehan nilai rata-rata kelas yang cukup signifikan. Seperti telah diketahui bersama bahwasanya mata pelajaran IPA menitik beratkan pembelajaran pada aspek kognitif, afektif, dan psikomotor sebagai pedoman perilaku kehidupan seharihari peserta didik. Untuk menyelesaikan kesulitan yang ada maka penerapan pembelajaran berbasis STEM dapat dijadikan salah satu metode inovasi untuk berkreasi, bertindak aktif, bertukar pikiran mengeluarkan pendapat, bertanya, berdiskusi, berargumentasi, bertukar informasi, dan memecahkan masalah yang ada bersama dengan kelompok diskusinya. Hal inilah yang membuat peserta didik berpikir lebih kritis, lebih kreatif dan inovatif sehingga mampu untuk memecahkan masalah-masalah yang kompleks dan efek selanjutnya adalah para peserta didik akan dapat memahami dan meresapi mata pelpelajaran IPA lebih jauh. Kendala yang masih tersisa yang perlu dibahas adalah hasil belajar yang dicapai pada siklus I ini belum seluruhnya memenuhi harapan yang sesuai dengan KKM mata pelajaran IPA di SMP Negeri 2 Gianyar yaitu 62. Oleh karenanya harus dilakukan upaya perbaikan lebih matang untuk siklus berikutnya.

Berdasarkan hasil refleksi pada siklus I, maka diadakan perbaikan pada siklus II dimana akan diberikan hadiah bagi kelompok yang maju dan membawakan hasil diskusinya dengan sangat baik dan berani. Dari awalnya masih malu malu karena takut salah, pada siklus ke II peserta didik menjadi lebih berani selain iming-iming hadiah, peserta didik juga telah mulai terbiasa dengan perlakuan pembelajaran berbasis STEM dikelasnya dan akan diberikan hadiah kejutan jika berhasil memperoleh nilai tertinggi saat penilaian hasil belajar berlangsung. Tidak memungkiri cara ini sangat aktif dalam meningkatkan perolehan hasil belajar peserta didik. Terbukti hasil yang diperoleh dari tes hasil belajar di siklus II menunjukkan bahwa kemampuan peserta didik dalam mengikuti pelpelajaran terjadi peningkatan yang signifikan dimana rata-rata nilai peserta didik mencapai 92,65. Hasil ini menunjukkan bahwa penerapan pembelajaran berbasis STEM yang telah diperbarui berhasil meningkatkan kemampuan peserta didik sesuai dengan harapan. Hal tersebut disebabkan karena beberapa faktor yaitu sebagai berikut.

Pertama, pembelajaran berbasis STEM berdampak pada kompetensi pengetahuan IPA karena dapat meningkatkan kemampuan berpikir kritis pada siswa. Pembelajaran pada abad 21 memberikan 
pengalaman belajar yang berorientasi pada pengembangan keterampilan berpikir kritis (Budiana, Sudana, \& Suwatra, 2013; Devi, P. S., \& Bayu, 2020). Pembelajaran berbasis STEM dapat membangun keterampilan berpikir kritis karena merujuk pada pendekatan yang terintegrasi dalam proses pendidikan yang berfokus pada pemecahan masalah dalam kehidupan sehari-hari yang nyata serta dalam kehidupan professional (Bahrum, Wahid, \& Ibrahim, 2018; Ngabekti, Prasetyo, Hardianti, \& Teampanpong, 2019). Penerapan pembelajaran berbasis STEM merupakan suatu strategi yang cocok bagi peserta didik apabila guru menginginkan mereka memiliki kemampuan keterampilan abad 21 mengingat peran pentingnya dalam menciptakan peradaban sebuah negara yang ditandai dengan kemajuan di bidang teknologi dan informasi dimana secara umum terdapat 4 ketrampilan (4C) yang dibutuhkan di abad 21 seperti yang telah disampaikan pada latar belakang di atas, antara lain: (1) Critical Thinking and Problem Solving; (2) Creativity and Innovation; (3) Communication; and (4) Collaboration (Izati, Wahyudi, \& Sugiyarti, 2018; Kembara, Rozak, \& Hadian, 2018). Penggunaan pembelajaran berbasis STEM mampu mendorong peserta didik untuk berpikir kritis dan menemukan solusi dalam suatu permasalahan selain mengupayakan agar peserta didik tidak hanya belajar menghapal dan menghayal tapi dapat membuatnya menjadi nyata dengan kreativitas, inovasi, dan kolaborasi.

Kedua, pembelajaran berbasis STEM berdampak pada kompetensi pengetahuan IPA karena dapat meningkatkan hasil belajar siswa. Penerapan STEM yang awalnya hanya bertujuan untuk meningkatkan minat peserta didik terhadap bidang STEM menjadi lebih luas. Keadaan ini muncul karena setelah diterapkan dalam pembelajaran, tenyata STEM mampu meningkatkan penguasaan pengetahuan, mengaplikasikan pengetahuan untuk memecahkan masalah, serta mendorong peserta didik untuk mencipta sesuatu yang baru. Penerapan STEM dapat didukung oleh berbagai metode pembelajaran (Jones \& Zanker, 2013; Twiningsih \& Sayekti, 2020). STEM yang bersifat integratif memungkinkan berbagai metode pembelajaran dapat digunakan untuk mendukung penerapannya (Mutakinati \& Anwari, 2018; Roberts et al., 2018). Pendekatan pembelajaran ini lebih menekankan pada sistem belajar yang terpusat pada siswa sehingga melibatkan keaktifan siswa dalam belajar. Selain itu pendekatan ini juga melatih keterampilan siswa sehingga siswa lebih menemukan, memahami konsep pembelajaran sehingga siswa lebih memiliki pengalaman, mengkonstruksi pengetahuan sehingga pengembangan diri siswa bisa tereksplorasi untuk meningkatkan hasil belajar siswa (Bahrum et al., 2018; Roberts et al., 2018).

Hasil penelitian ini ternyata memberikan efek utama bagi peserta didik dalam proses belajarnya yang dapat dilihat pengaruhnya yang sangat signifikan dari hasil belajarnya. Temuan ini membuktikan bahwa guru sudah tepat memilih ramuan dari penyakit yang ada pada diri peserta didik dimana peserta didik menginginkan suatu proses belajar yang inovatif, efektif, bermakna, dan menyenangkan. Hal ini sejalan pula dengan temuan-temuan peneliti lain seperti yang dilakukan oleh Heldisari (2020) dan Puspitasari (2018) yang pada dasarnya menyatakan bahwa metode pembelajaran yang diterapkan berpengaruh terhadap hasil belajar peserta didik. STEM telah banyak diterapkan dalam pembelajaran. Keadaan ini ditunjukkan dari hasil penelitian yang mengungkap bahwa penerapan STEM dapat meningkatkan prestasi akademik dan non-akademik peserta didik.

Implikasi penelitian ini memberikan dampak meningkatkan kemampuan berpikir kritis siswa dan menciptakan suasana pembelajaran menjadi lebih aktif sehingga dapat meningkatkan hasil belajar siswa. Terkait dengan hasil yang diperoleh melalui tindakan berupa Penerapan pembelajaran berbasis STEM, diharapkan pada setiap guru khususnya guru IPA agar tidak berhenti unuk berinovasi dan menetukan perlakuan yang cocok diberikan pada peserta didik karena pada dasarnya peserta didik memiliki sifat yang heterogen dimana kita sebagai seorang guru harus mampu untuk berpikir kreatif dan inovatif agar peserta didik tidak bosan menerima pembelajaran yang diberikan.

\section{Simpulan}

Kemampuan peserta didik dalam mengikuti pembelajaran berbasis STEM meningkat secara signifikan. Dapat disimpulkan bahwa penerapan pembelajaran berbasis STEM dapat meningkatkan minat siswa dalam belajar sehingga berdampak pada peningkatan hasil belajar IPA pada siswa.

\section{Daftar Rujukan}

Anika, \& Fajar. (2020). Efektivitas Model Pembelajaran Kooperatif Tipe Make-A Match Dalam Meningkatkan Kompetensi Sikap Siswa dan Kompetensi Pengetahuan Siswa Pada Pelajaran IPS. $\begin{array}{llll}\text { Jurnal Ilmiah Sekolah 80-85. } & \text { Dasar, }\end{array}$ https://doi.org/http://dx.doi.org/10.23887/jisd.v4i1.24047.

Ari, N. L. P. M., \& Wibawa, I. M. C. (2019). Pengaruh Model Pembelajaran Make A Match Terhadap Motivasi Belajar Ilmu Pengetahuan Alam. Mimbar PGSD, 189-197. 
Bahrum, Wahid, \& Ibrahim. (2018). Integration of STEM Education in Malaysia and Why to STEAM. International Journal of Academic Research in Business and Social Sciences, 7(6), 645-654. https://doi.org/https://doi.org/10.6007/ijarbss/v7-i6/3027.

Budiana, Sudana, \& Suwatra. (2013). Pengaruh Model Creative Problem Solving ( CPS ) Terhadap Kemampuan Berpikir Kritis Siswapada Mata Pelajaran IPA Siswa Kelas V SD. Mimbar PGSD Undiksha, 1(1). https://doi.org/http://dx.doi.org/10.23887/jjpgsd.v1i1.816

Devi, P. S., \& Bayu, G. W. (2020). Berpikir Kritis dan Hasil Belajar IPA Melalui Pembelajaran Problem Based Learning Berbantuan Media Visual. MIMBAR PGSD Undiksha, 8(2), 238-252. https://doi.org/http://dx.doi.org/10.23887/jjpgsd.v8i2.26525.

Febriana. (2017). Efektivitas Model Pembelajaran Berbasis Kompetensi Dengan Pendekatan Dunia Kerja Pada Program D3 Tata Boga. Cakrawala Pendidikan, 36(1), 148-155. Retrieved from https://journal.uny.ac.id/index.php/cp/article/view/8891/pdf.

Hartanti, H., Fidiyanti, N., Ruhimat, M., \& Winarti, M. (2017). Effect Of Implementation Of Cooperative Learning Model Make A Match Technique On Student Learning Motivation In Social Science Learning.

Heldisari, H. (2020). Efektivitas Metode Eurhythmic Dalcroze Terhadap Kemampuan Membaca Ritmis Notasi Musik. Jurnal Ilmiah Pendidikan Dan Pembelajaran, 4(3). https://doi.org/http://dx.doi.org/10.23887/jipp.v4i3.28223.

Izati, S. N., Wahyudi, \& Sugiyarti, M. (2018). Project Based Learning Berbasis Literasi untuk Meningkatkan Hasil Belajar Tematik. Jurnal Pendidikan: Teori, Penelitian, Dan Pengembangan, 3(9), 1122-11271127. https://doi.org/10.17977/jptpp.v3i9.11508.

Jones, \& Zanker, N. P. (2013). Applying laser cutting techniques through horology for teaching effective STEM in design and technology. Design and Technology Education, 18(3), 21-34. Retrieved from https://ojs.lboro.ac.uk/DATE/article/view/1874.

Kanematsu, \& Barry. (2016). STEM and ICT Education in Intelligent Environments. Switzerland: Springer International Publishing.

Kapila, \& Iskander. (2014). Lessons learned from conducting a K12 project to revitalize achievement by using instrumentation in Science Education. Journal of of STEM Education, 15(1), 46-51. Retrieved from https://eric.ed.gov/?id=EJ1034678.

Kembara, Rozak, \& Hadian. (2018). Research-based Lectures to Improve Students' 4C (Communication, Collaboration, Critical Thinking, and Creativity) Skills. Proceedings of the Second Conference on Language, Literature, Education, and Culture (ICOLLITE), 1(1). https://doi.org/https://dx.doi.org/10.2991/icollite-18.2019.50, . 20019.11.

Kurnia, Damayani, \& Kiswoyo. (2019). Keefektifan Model Pembelajaran Number Head Together (NHT) Berbantu Media Puzzle Terhadap Hasil Belajar Matematika. Jurnal Ilmiah Sekolah Dasar, 3(2), 192. https://doi.org/https://doi.org/10.23887/jisd.v3i2.17772.

Mutakinati, \& Anwari. (2018). Analysis Of Students ' Critical Thinking Skill Of Middle School Through Stem Education Project-Based Learning. Jurnal Pendidikan IPA Indonesia, 7(1), 54-65. https://doi.org/https://doi.org/10.15294/jpii.v7i1.10495.

Ngabekti, Prasetyo, Hardianti, \& Teampanpong. (2019). The Development of STEM Mobile Learning Package Ekosistem. Jurnal Pendidikan IPA Indonesia, 8(1), 81-88. https://doi.org/https://doi.org/10.15294/jpii.v8i1.16905.

Nuraziza, \& Suwarma. (2018). Menggali Keterampilan Creative Problem Solving yang dimiliki Peserta didik SMP melalui Pembelajaran IPA Berbasis STEM. Jurnal WAPFI (Wahana Pendidikan Fisika), 3(1), 55-61. https://doi.org/https://doi.org/10.17509/wapfi.v3i1.10941.

Octaviyani, I., Kusumah, Y. S., \& Hasanah, A. (2020). Peningkatan Kemampuan Berpikir Kreatif Matematis Siswa Melalui Model Project-Based Learning Dengan Pendekatan STEM. Journal on Mathematics Education Research Universitas Pendidikan Indonesia, 1(1), 10-14. Retrieved from https://ejournal.upi.edu/index.php/JMER/article/view/24569.

Pratama, \& Dkk. (2017). Pengembangan Multimedia Interaktif Berbasis Model Vak Pada Mata Pelajaran IPA Siswa Kelas V Di Sdn 2 Banjar Bali. Jurnal Edutech Undiksha, 5(1), 132-141. Retrieved from 
https://ejournal.undiksha.ac.id/index.php/JEU/article/view/20635/12617.

Puspitasari. (2018). Metode Pembelajaran Bermain Peran Pada Pembelajaran Bahasa Indonesia. Jurnal Cakrawala Pendas, I(1), 55-64. https://doi.org/http://dx.doi.org/10.31949/jcp.v1i1.347.

Putri, N. P. L. K., Kusmariyatni, N., \& Murda, I. N. (2018). Pengaruh Model Pembelajaran Inkuiri Terbimbing Berbantuan Media Audio-Visual Terhadap Hasil Belajar IPA. Mimbar PGSD, 6(3), 153-160.

Putri, Suwatra, \& Tegeh. (2018). Pengaruh Model Pembelajaran PBL Berbantuan Media Gambar Terhadap Hasil Belajar IPA Siswa Kelas III SD. Jurnal Mimbar Ilmu, 23(1), 53-64. https://doi.org/http://dx.doi.org/10.23887/mi.v23i1.16407.

Rahayu, S. (2017). Penerapan Model Problem Based Learning (PBL) untuk Meningkatkan Keterampilan Berpikir Kritis dan Prestasi Belajar Siswa (Studi pada Mata Pelajaran IPA Kelas V Pada SDN Gugus II Raflesia Talang Empat Kabupaten Bengkulu Tengah). Jurnal Ilmiah Teknologi Pendidikan, 7(2), 98-110.

Redhana, I. W. (2013). Model Pembelajaran Berbasis Masalah Dan Pertanyaan Socratik Untuk Meningkatkan Keterampilan Berpikir Kritis Siswa. Jurnal Cakrawala Pendidikan, (3), 351-365. https://doi.org/10.21831/cp.v0i3.1136.

Roberts, Jackson, Mohr-Schroeder, Bush, Maiorca, Cavalcanti, \& Cremeans. (2018). Students' Perceptions of STEM Learning After Participating in a Summer Informal Learning Experience. International Journal of STEM Education, 5(1). https://doi.org/https://doi.org/10.1186/s40594-018-0133-4.

Salame, I. I., \& Nazir, S. (2019). The Impact of Supplemental Instruction on the Performance and Attitudes of General Chemistry Students. International Journal of Chemistry Education Research. https://doi.org/10.20885/ijcer.vol3.iss2.art1.

Sugiyono. (2016). Metodologi Pendidikan. Bandung: Alfabeta.

Torlakson. (2014). Innovate: A Blueprint For Science, Technology, Engineering, and Mathematics in California Public Education. California: State Superintendent of Public Instruction.

Twiningsih, A., \& Sayekti, T. (2020). Peningkatan Keterampilan Berhitung Siswa Melalui Media Kotak Ajaib Berbasis Stem Pada Materi Konsep Penjumlahan. Jurnal Pendidikan Dasar, 11(1). https://doi.org/doi.org/10.21009/JPD.011.02.

Wulandari, Sudatha, \& Simamora. (2020). Pengembangan Pembelajaran Blended Pada Mata Kuliah Ahara Yoga Semester II di IHDN Denpasar. Jurnal Edutech Undiksha, 8(1), 1-15. https://doi.org/http://dx.doi.org/10.23887/jeu.v8i1.26459.

Yuliati, \& Lestari. (2019). Penerapan Model Creative Problem Solving untuk Meningkatkan Hasil Belajar Siswa pada Pembelajaran Ilmu Pengetahuan Alam Di Sekolah Dasar. Jurnal Cakrawala Pendas, 5(1). https://doi.org/http://dx.doi.org/10.31949/jcp.v5i1.1200. 